\title{
Characterization of the Origin of Pollutants in Groundwater from Biostatistical Tests: The Case of Catchment Ehania, South-Eastern Côte d'Ivoire
}

\author{
Brou Dibi $^{1}$, Arthur Brice Konan-Waidhet ${ }^{1}$, Felix Koffi Konan ${ }^{1}$, Charles Sagne Yao ${ }^{1}$, \\ Alex Kouadio Zilé ${ }^{1}$, Issiaka Savané ${ }^{2}$, Dago Gnakri ${ }^{1}$ \\ ${ }^{1}$ Université Jean Lorougnon Guedé Daloa, Daloa, Côte d'Ivoire \\ ${ }^{2}$ Université Nangui Abrogoua, Abidjan, Abidjan, Côte d'Ivoire \\ Email: brou_dibi@yahoo.fr
}

Received July 2, 2013; revised August 5, 2013; accepted September 1, 2013

Copyright (C) 2013 Brou Dibi et al. This is an open access article distributed under the Creative Commons Attribution License, which permits unrestricted use, distribution, and reproduction in any medium, provided the original work is properly cited.

\begin{abstract}
The threat of agro-industrial exploitations on the quality of groundwater resources has become a major concern for the world's population, mainly in agricultural areas. To solve this problem, several methods such as vulnerability to pollutants and statistics methods, have been adopted to protect these groundwaters. In this study, statistical tests were used to determine the likely source of pollutants in the groundwater resources. First, we made a comparative analysis and then analyzed pollutants parameters using Kohonen self-organizing map (SOM) which allows basic on the similarity to help out any correlation between the physic-chemical parameters. To validate these results, a land use map was developed to identify the sources of pollutants in production functions of different activities taking place on the catchment area. The results indicate very high levels of certain pollutants such as $\mathrm{NO}_{3}^{-}, \mathrm{Cl}^{-}$and $\mathrm{SO}_{4}^{2-}$ with generally higher than World Health Organization (WHO) standards values. These high levels observed could be attributed to the generally free nature of aquifers alteration and sedimentary formations in areas of high agro-industrial production. The analysis of the data from SOM method reveals a strong correlation between pollutants $\left(\mathrm{NO}_{3}^{-}, \mathrm{SO}_{4}^{2-}, \mathrm{Cl}^{-}\right)$and conductivity showing the likely origin of these surface pollutants, an origin that is linked to the existence of larges agro-industrials exploitations. These results are reinforced by those of the overlay map of the sampling sites on the land use map, which shows a strong coincidence between high values of pollutants and production areas of the pollutants that are agro-industrial exploitations. These areas of coincidence are observed in the north where banana's industrials plantations are found less visible and mostly in the southwest part which is one of the largest oil palm plantations in the world (36,000 hectares).
\end{abstract}

Keywords: Characterization; Origin of Pollutants; Groundwater; Biostatistical Tests; Catchment Ehania

\section{Introduction}

The groundwater resources have become the best source of drinking water in rural and urban populations in recent years. However, this resource although considered safe because supposed to be free from pollution, is threatened due to the production of fertilizers and increased agro-industrial farms [1]. According to [2], groundwater resources are at higher risk as its remediation is very difficult. The major anthropogenic activities for continuous groundwater quality deterioration are urbanization, industrialization and agriculture run off.

The importance of these threats often results in the accumulation of nitrate in freshwater systems as it indicates through several studies $[3,4]$. These threats that concerned developed countries were deported to developing countries such as Côte d'Ivoire. Several works have identified the impact of agro-industrial exploitations on water resources in general and particularly on the underground waters [5-8]. Therefore, on Ehania catchment, in the southeast of Côte d'Ivoire, these problems are exacerbated by the existence of the largest agro-industrial palm oil plantation in the world (36,000 hectares), more large banana plantations (5000 hectares) [9] and many village plantations of oil palm, rubber and cocoa [10]. Indeed, their quality could be influenced by natural processes such as soil erosion, precipitation, evaporation and dissolution of 
rocks [11]. These threats have been studied several times in the region. However, these studies were limited to the assessment of vulnerability to pollution that identifies risk areas and sometimes potential sources of pollution from the land. They do not show the traceability of pollutants. Also, the mechanism underlying the mineralization that shows the transfer mode of different pollutants in solution is not manageable. Either, the use of statistical tests could help to determine the likely source of pollutants in the groundwater resources as it indicates by the works of [8].

The aim of this study is to determine the probable origins of pollutants from mineralization process to separate the anthropogenic causes deep from multivariate statistical tests origins. A statistical test will be conducted to characterize the mechanisms that govern the transition to different pollutants solution to identify their possible origin. The results obtained will be validated by land use map to identify areas of production of pollutants. This study will thus assess the impact of agro-industrial exploitations on groundwater quality.

\section{Material and Methods}

\subsection{Study Area}

The study area selected for this research project (Figure 1) is located in south-eastern Côte d'Ivoire, precisely in the region of South-Comoé. It is located between Western longitudes $2^{\circ} 45^{\prime} \mathrm{W}$ and $3^{\circ} 05^{\prime} \mathrm{W}$ and Northern latitudes $5^{\circ} 10^{\prime} \mathrm{N}$ and $5^{\circ} 45^{\prime} \mathrm{N}$.

It covers about $342 \mathrm{~km}^{2}$. The area is in the tropical climate characterized by four seasons with two dry (large and small) and two wet (large and small). The geological formations are varied from shale in the northern part to the sedimentary formations in the South. These different types of geological formations indicate the existence of different aquifers that are aquifers in sedimentary formations (Quaternary and Tertiary), weather aquifers and

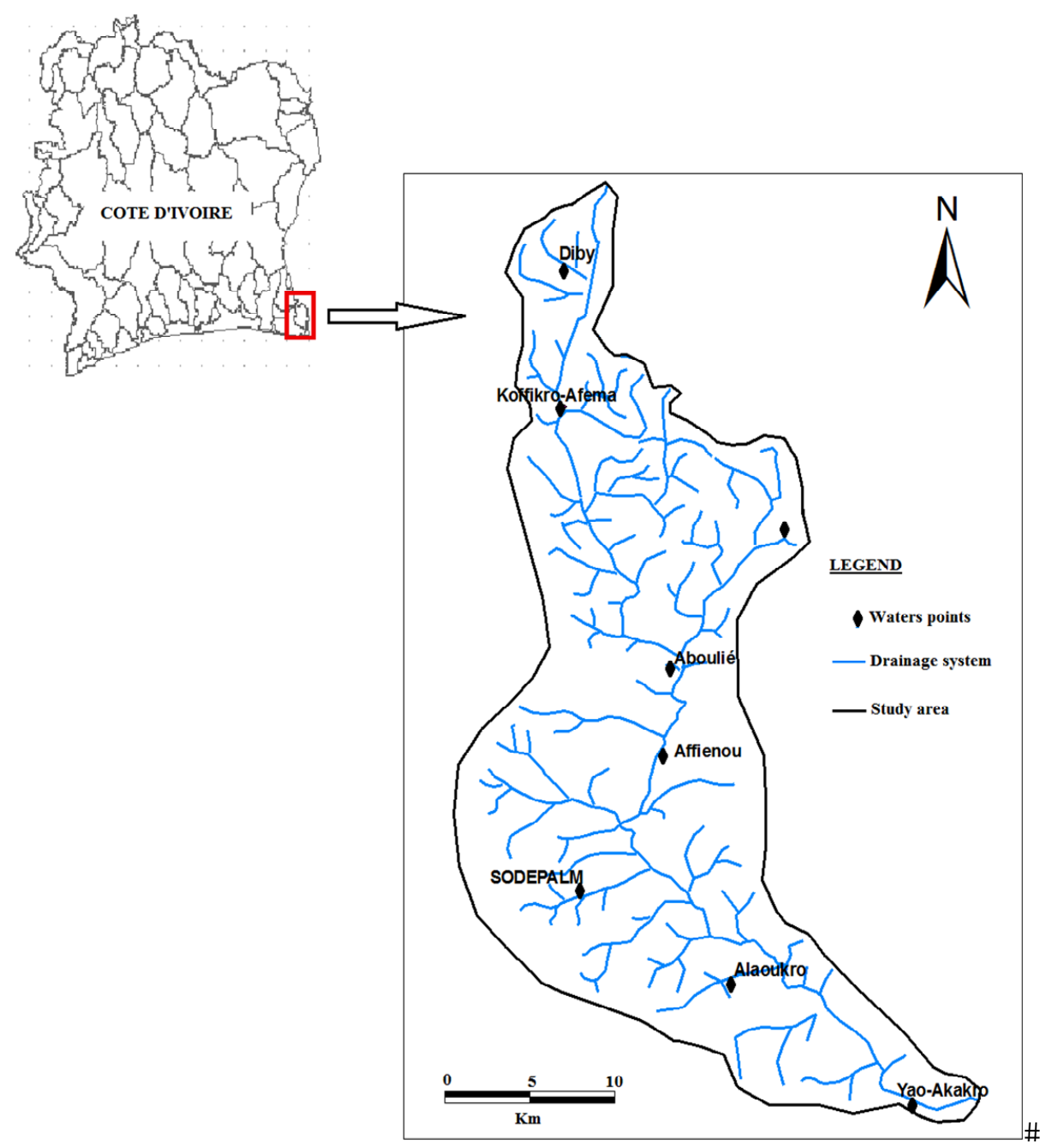

Figure 1. Study area. 
fractured. Concerning topographic, relief is very rugged with elevations generally ranging from 100 to $200 \mathrm{~m}$ up to $400 \mathrm{~m}$. The hydrographic network which is an indicator of recharge is very dense in the north and less dense in the South where we have sedimentary formations. Soils consist of reworked soil and sometimes indurated throughout with some portions of hydromorphic soil and gley pseudogley especially along the river Ehania.

\subsection{Collect Datas}

The physico-chemical data collected during the campaign are composed of physical parameters $(\mathrm{pH}$ and electrical conductivity) measured in situ using a multiparameter probe. Samples were then collected on 31 sites and stored at $5^{\circ} \mathrm{C}$ in a cooler for a laboratory analysis of the Research Center for Oceanography (CRO) in Abidjan (Côte d'Ivoire). Analytical methods vary depending on the chemical elements, $\mathrm{Ca}^{2+}, \mathrm{Mg}^{2+}, \mathrm{Cl}^{-}$and $\mathrm{HCO}_{3}^{-}$by titration (acid titration), $\mathrm{Na}^{+}$et $\mathrm{K}^{+}$by atomic absorption flame, $\mathrm{Fe}^{2+}, \mathrm{Mn}^{2+}, \mathrm{SO}_{4}^{2-}, \mathrm{NO}_{3}^{-}$spectrometry molecular absorption. The parameters have been treated by the self-organizing map of Kohonen (SOM).

The satellitale images were then used for mapping the land use. These Landsat ETM+ images in January 2000 and concern the scene 195-56.

\subsection{Methods}

\subsubsection{Origin of Pollutants}

In order to know the possible causes of pollutants observed in groundwater, statistical tests were performed. Thirst, we adopted standard methods [12] like spatial analysis to assess spatial variation. Then the self-organizing map of Kohonen (SOM) [13,14] was applied. Due to their efficiency, artificial neural networks (ANN) with self-organizing map (SOM) algorithm are appropriate methods to model non-linear data [15] and demonstrated their utility in environmental decision-making [16-18]. The SOM method was adopted in this study because of its high quality handle extreme data (Figure 2). It allows by the similarity to get out a correlation between these parameters. Thus, knowing the role of each parameter in the groundwater resources and the various sources of pollutants production, it is then easy to identify the likely source of water pollution in the area.

The Self-Organizing Map (SOM) $[13,14]$ was used to classify the samples according to physic-chemical characteristics. The data set was arranged as a matrix of 32 rows (i.e., the 32 sampling sites) and 6 columns (i.e., the 13 physic-chemical parameters). For more details concerning the SOM algorithm and its applications, we refer the readers [10,16-22].

We checked whether relevant groups of samples characterized distinct groups by performing a hierarchical

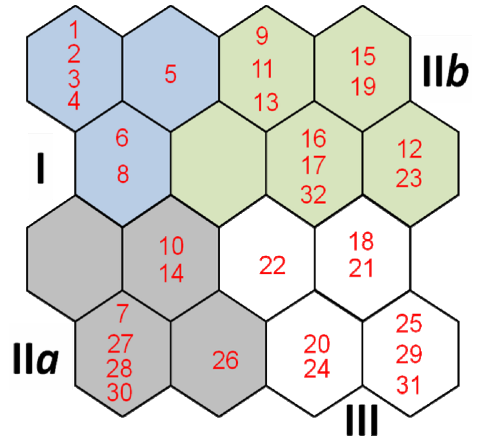

Figure 2. Classification of samples using physico-chemical data through the learning process of the self-organizing map. Numbers 1 to 32 represent samples.

cluster analysis (Ward's linkage and Euclidean distance). To do so, we used a new matrix $(16 \times 32$, output neurons $\times$ physico-chemical parameters) of the connection intensity values estimated by the SOM. The number of clusters was defined by applying the Davies-Bouldin index (DBI), in which minimum values indicate low variance within clusters and high variance between clusters [23].

The analysis was carried out using the SOM Toolbox ${ }^{\circ}$ [20] for Matlab ${ }^{\odot}$ in a PC platform.

\subsubsection{Elaboration of Land Use Map}

The elaboration of land use map requires the use of satellite images. For this study, we used the Landsat 7 ETM + scene 195-56. It will allow mapping different layers which could produce or contribute to produce pollutants.

Corrected images that cover the watershed Ehania have been combined several times to identify the combination that would better discriminate between different types of soil occupation. Thus, we conducted the principal component analysis (PCA), realizing the colored compositions and the normalized vegetation index (NDVI). The training plots were subsequently chosen for the determination of different types of land use. The resulting map will subsequently subject to validation of results from the confusion matrix and control plots.

\section{Results and Discussions}

Analysis of the various physical and chemical parameters (Table 1) shows a large variability in parameters. First, concerning the physical parameters, $\mathrm{pH}$ ranges of 4.2 to 7 with $84 \%$ of the samples having a value lower than 6.5 , recommended by the WHO standard. These values indicate groundwaters in this zone are acids. Conductivities remain below WHO standards despite the peaks observed in places. The analysis of chemical characteristics shows that the levels of the major ions particularly cations $\left(\mathrm{Na}^{+}\right.$, $\mathrm{K}^{+}, \mathrm{Mg}^{2+}, \mathrm{Ca}^{2+}, \mathrm{Mn}^{2+}, \mathrm{Fe}^{2+}$ ) are generally lower than WHO standard. The analysis of the graph (Figure 3), which characterizes the pollutants $\left(\mathrm{NO}_{3}^{-}, \mathrm{Cl}^{-}\right.$and $\left.\mathrm{SO}_{4}^{2-}\right)$ 
Table 1. Mean and standard deviation of physico-chemical parameters.

\begin{tabular}{cccccccccccccc}
\hline Parameters & $\mathbf{N a}^{+}$ & $\mathbf{K}^{+}$ & $\mathbf{C a}^{2+}$ & $\mathbf{C l}^{-}$ & $\mathbf{M g}^{2+}$ & $\mathbf{S O}_{4}^{2-}$ & $\mathbf{N O}$ & $\mathbf{p H}$ & $\mathbf{C o n d}$. & $\mathbf{S a l .}$ & $\mathbf{H C O}_{3}^{-}$ & $\mathbf{F e}^{2+}$ & $\mathbf{M n}^{2+}$ \\
\hline Average & 1.95 & 18.87 & 15.92 & 9.30 & 7.28 & 18.30 & 53.57 & 5.54 & 212.47 & 0.10 & 83.79 & 0.04 & 0.00 \\
Stand. Dev. & 0.21 & 2.64 & 1.89 & 18.84 & 0.86 & 37.07 & 39.49 & 0.79 & 219.29 & 0.11 & 9.95 & 0.04 & 0.00 \\
WTO Stand. & 150 & 12 & 270 & 200 & 50 & 250 & 50 & $6.5-8.5$ & 2100 & 1000 & 200 & 0.3 & 0.1 \\
\hline
\end{tabular}

Stand. Dev.: Standard Deviation; WTO Stand.: WTO (World Trade Organization) Standard; Unities: $\mathrm{Na}^{+}, \mathrm{K}^{+}, \mathrm{Ca}^{2+}, \mathrm{NO}_{3}^{-}, \mathrm{Sal}(\mathrm{Salinity}) \mathrm{HCO}_{3}^{-}, \mathrm{Fe}^{2+}$, Mn ${ }^{2+}$, $\mathrm{Cl}^{-}, \mathrm{Mg}^{2+}$ and $\mathrm{SO}_{4}^{2-}$ are in $\mathrm{mg} / \mathrm{L}$; Cond. (Conductivity): $\mu \mathrm{s} / \mathrm{Cm}$.

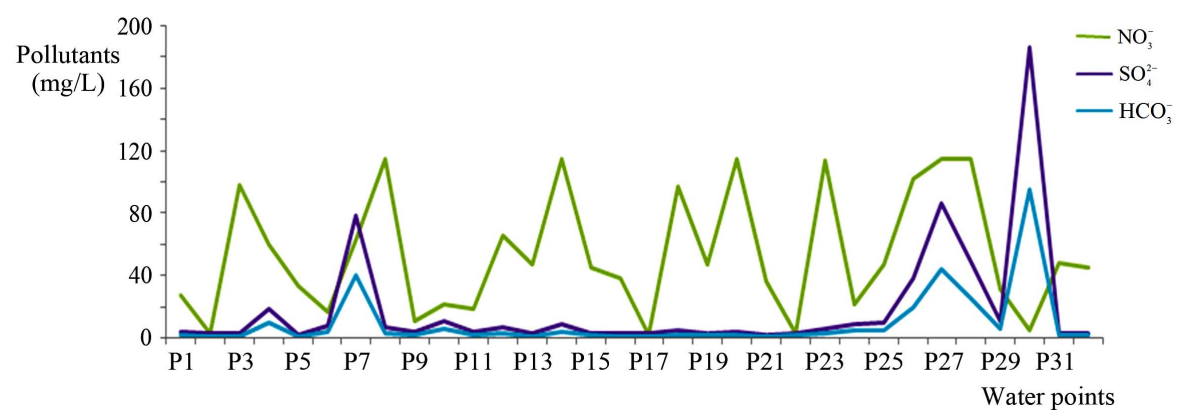

Figure 3. Spatial variation in concentrations of major pollutants $\left(\mathrm{NO}_{3}^{-}, \mathrm{SO}_{4}^{2-}, \mathrm{Cl}^{-}\right)$.

shows that the concentrations of $\mathrm{Cl}^{-}$and $\mathrm{SO}_{4}^{2-}$ are low and below WHO standards despite the peak obtained at the 31 corresponding to the sample borehole village Diby. This could be attributed to an accidental pollution. For $\mathrm{NO}_{3}^{-}$, these concentrations vary between 2 and $115 \mathrm{mg} / \mathrm{L}$ with an average of $53.57 \mathrm{mg} / \mathrm{L}$, which is higher than the WHO standard.

These concentrations vary from one well to another with peaks observed in wells that capture the weathered aquifers and sedimentary formations, probably due to the existence of large agro-industrials farms. Indeed, the weathered layers and sedimentary formations are highly vulnerable to pollution phenomena due to the overall free and continuous nature of these aquifers. This is not the case at the aquifers that are more protected at the base. This results in low pollutants in general and particularly of $\mathrm{NO}_{3}^{-}$observed in the wells. Regarding the peak observed for the $\mathrm{Cl}^{-}$and $\mathrm{SO}_{4}^{2-}$ in sample 30, that represent the borehole village Diby located in the basement where the $\mathrm{NO}_{3}^{-}$is negligible, it could be attributed to the difference between production sources of these pollutants. Indeed, $\mathrm{Cl}^{-}$and $\mathrm{SO}_{4}^{2-}$ could come from the dissolution of sedimentary rocks; this is not the case for $\mathrm{NO}_{3}^{-}$which usually comes from the surface.

To determine the origin of the mineralization, the physicochemical data analyzes were processed from the selforganizing map of Kohonen (SOM). The samples were classified by the SOM according to their physcochemical characteristics in the 20 output nodes, so that each node included samples with similar characteristics (Figure 4).

The hierarchical classification analysis (Figure 2) has brought together all the cells of the Kohonen map into four subgroups (I-IV). As in Figure 5, it represents the weight of the various physico-chemical parameters considered in the grouping of each unit defined by the hierarchical cluster analysis used. Group I represents mainly the parameters of samples 1;2 and 5, which correspond to the structures of the village and its surroundings Ehania. This includes a well and two boreholes of this locality. This correlation could then be justified by the nature of the captured geological formations that are usually made of shale. However, the low concentrations observed and the low conductivity values might suggest a residence time of parameters relatively short for groundwater in these aquifers. The water has not had sufficient time to dissolve the rocks to ensure the passage of major ions in solution whose presence in groundwater indicates a residence time long enough.

Group II is divided into two sub-groups (IIa and IIb). IIa subgroup contains samples 7; 10;14;26;27; 28 and 30 .

These samples are generally characterized by high levels of $\mathrm{Cl}^{-}, \mathrm{SO}_{4}^{2-}$, salinity, $\mathrm{NO}_{3}^{-}$. These high levels correspond to high values of conductivity. However, $\mathrm{Cl}^{-}$and $\mathrm{SO}_{4}^{2-}$ could come from fertilizer containers of chlorinated contaminants, sea spray and salt weathering of hard rock [24]. These salts are leached by rainwater and irrigation and trained to groundwater. In our study area, the good correlation between $\mathrm{Cl}^{-}$and conductivity might suggest to mineralization related to the residence time of groundwater in the rocks. Indeed, the conductivity shows the degree of mineralization of water. The higher the con- 

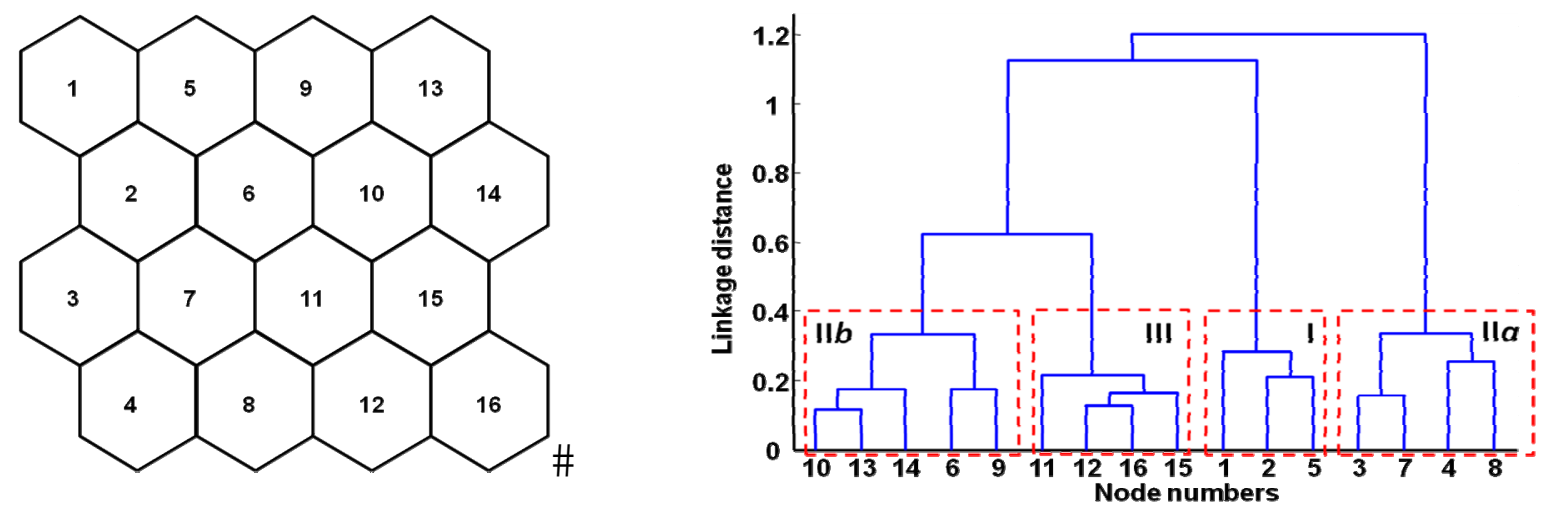

Figure 4. a) Self-organizing map (SOM) (16 nodes) b) Hierarchical clustering of the SOM nodes with a Ward linkage method and a Euclidean distance: the numbers (i.e. ranging from 1 to 16) correspond to those assigned on each node of the SOM. The four boxes correspond to the clusters selected from the Davies-Bouldin index (DBI, see material and methods for more details).
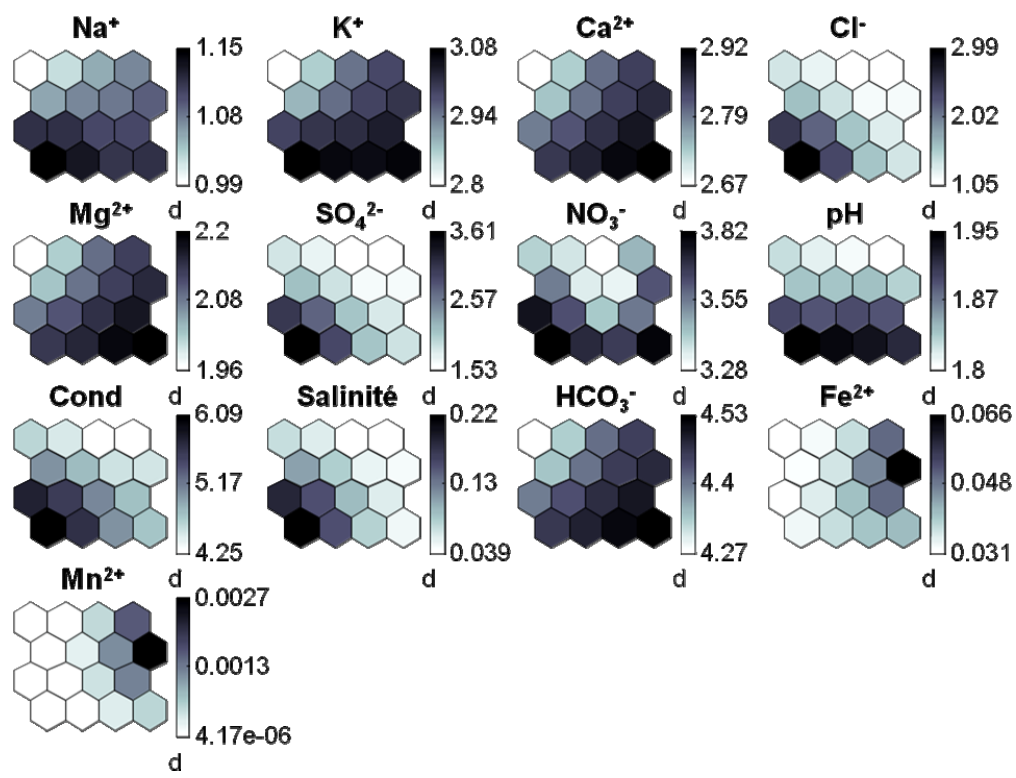

Figure 5. Visualization of physico-chimical variables on the self-organizing map (SOM). Dark represents high values and light represents low ones. Cond.: Conductivity.

ductivity, the higher the water is mineralized. However, we note a good correlation between $\mathrm{Cl}^{-}, \mathrm{SO}_{4}^{2-}, \mathrm{NO}_{3}^{-}$ and salinity. Either, the $\mathrm{NO}_{3}^{-}$does that come from the surface or from atmospheric nitrogen or from anthropogenic pollutants [25]. The presence of these pollutants could be explained by a surface origin. Thus, the mineralization of groundwater in the area is related to the transfer of these ions from the surface to depth. These results are further supported by the low concentrations of ions come from the dissolution of pre-existing rocks such as $\mathrm{Ca}^{2+}, \mathrm{Mg}^{2+}, \mathrm{Na}^{+}$and $\mathrm{K}^{+}$. These surface pollutants likely come from pesticides used in the agro-industrial exploitations. This observation could still justify the existence in these areas of high pollution sources that are agro-industrial farms of palm oil and banana. Several studies indicate that their concentrations increase due to the large amount of chemical fertilizer used in agriculture [26]. To this must be added the wastewater and waste residue from the processing of agricultural products. All this will lead toincreased levels of pollutants such as phosphate, chloride, and sulfate in groundwater [27]. This class is probably the most important may indicate pollution from surface.

Class IIb groups across samples 9 - 32 with particularity in samples 12 and 23 corresponding to the wells and localities Baffia and M'Possa that contain high levels of iron and manganese. These two parameters which are not dangerous to human health could have an impact on the taste and their presence in water can come from either a deep origin or an anthropogenic origin. Iron and manganese are naturally contained in the components of the Earth consist of crystalline and sedimentary rocks. The 
action of erosion alters these rocks and release components which could be iron and manganese by chemical affinity [28]. However, these two parameters may have an anthropogenic origin and therefore superficial mainly because of their low correlation with conductivity.

Class III includes samples $18 ; 20 ; 21 ; 22 ; 24 ; 25 ; 29$ and 31 . The analysis of these samples shows that this class contains waters rich in $\mathrm{Ca}^{2+}, \mathrm{Mg}^{2+}$ and $\mathrm{HCO}_{3}^{-}$ which come from the dissolution of the enclosing rocks and expressing mineralization that is related to the residence time. However, the concentrations of these parameters remain weak and we note a lack of correlation between these parameters and the conductivity that expresses the degree of mineralization. These phenomena are observed in the wells of M'gbasso, Toliesso and Baffia localities that are on crystalline basement and crystallophyllian. The analysis of this class shows the mineralization associated to residence time. Thus concerning Ehania catchment, mineralization of groundwater increase due to the expansion of agricultural land and the intensive development of agriculture, which also leads to the salinization of groundwater [29].

To support these results, the land use map of Ehania catchment was developed derived from Landsat ETM+ images (Figure 6). The confusion matrix of the different classes of land use (Table 2) indicates that the overall mapping accuracy is $73.53 \%$. This value allow to conclude that different types of land in the study region were fairly well discriminated.

It highlights four classes that are bare soils that occupy small pockets throughout the study area, fallow usually contain the villagers farms and cover a good portion of the study area from north to south. We then have 2 types of agro-industrials farms that are Banana plantations in the north and oil palm plantations in the suth of the catchment. The superposition of the map obtained in localities with high concentrations shows that these areas coincide with potential areas of production of pollutants. Thus, in the northern part of the localities Koffikro, Ayebo, Diby and Baffia with $\mathrm{NO}_{3}^{-}$concentrations of $115 ; 97.5 ; 115$ and $66 \mathrm{mg} / \mathrm{L}$ are located either downstream or in the middle of the industrial plantations of bananas. In the south, large industrial oil palm plantations have greatly disturbed the groundwater quality in these particular localities of these areas. This is case of Aboulie, Kouakro, Awran and Sodepalm with $\mathrm{NO}_{3}^{-}$ concentrations of $114.7 ; 115 ; 101.9$ and $115 \mathrm{mg} / \mathrm{L}$. Indeed, these plantations heavily used pesticides, release the nitrogen in nature that will be transformed into $\mathrm{NO}_{3}^{-}$ (nitrosation) and then in $\mathrm{NO}_{3}^{-}$(nitrification) [25]. These two types of exploitations could be potential sources of production of pollutants from surface sources such as the $\mathrm{Cl}^{-}, \mathrm{SO}_{4}^{2-}$, salinity and $\mathrm{NO}_{3}^{-}$.
Table 2. Confusion matrix for classification.

\begin{tabular}{ccccccc}
\hline & Forest & $\begin{array}{c}\text { Ind. } \\
\text { Farm1 }\end{array}$ & $\begin{array}{c}\text { Ind. } \\
\text { Farm 2 }\end{array}$ & $\begin{array}{c}\text { Fal.-vil. } \\
\text { plant. }\end{array}$ & $\begin{array}{c}\text { Barre } \\
\text { soil }\end{array}$ & Waters \\
\hline Forest & $\mathbf{8 1 . 1 3}$ & 15.25 & 0 & 0.67 & 0.15 & 0 \\
Ind. farm1 & 17.86 & $\mathbf{7 2 . 1 8}$ & 0 & 34.38 & 0 & 0 \\
Ind. Farm 2 & 0 & 0 & $\mathbf{9 2 . 2 3}$ & 6.12 & 0.45 & 0 \\
Fal.-vil. plant. & 0.53 & 12.57 & 7.77 & $\mathbf{5 8 . 1 0}$ & 10.77 & 5.13 \\
Barre soil & 0.16 & 0 & 0 & 0.27 & $\mathbf{8 7 . 5 6}$ & 1.96 \\
Waters & 0.32 & 0 & 0 & 0 & 1.06 & $\mathbf{9 2 . 9 1}$ \\
\hline
\end{tabular}

Ind. Farm: Industrials farm; Fa.-vil plant: Fallow-villagers plantation.

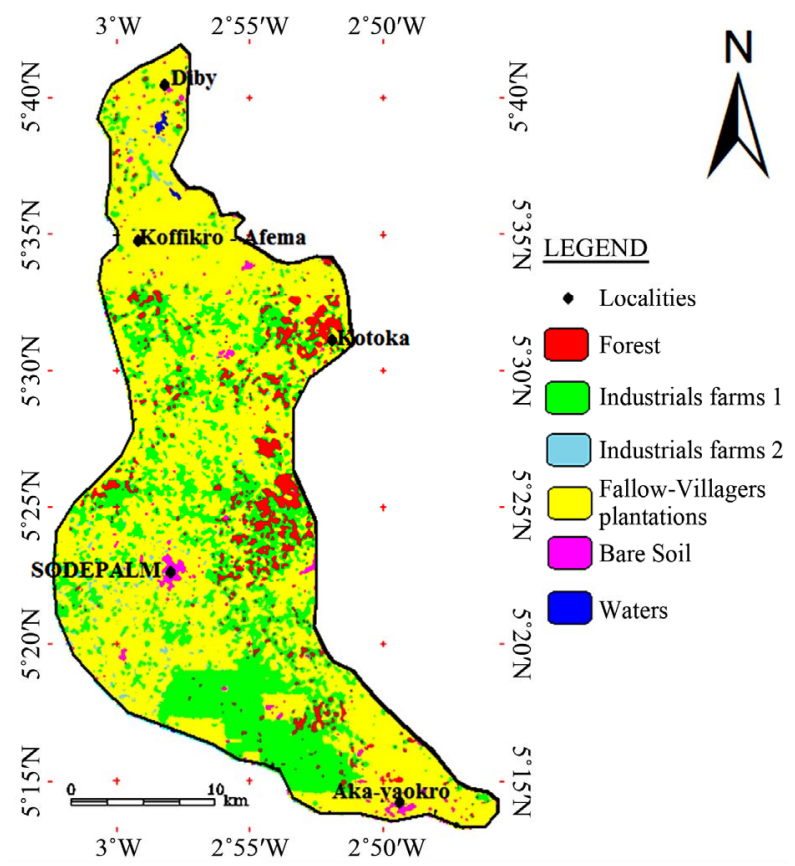

Figure 6. Land use map.

At all, we observe a good coincidence between the concentrations and pollutants potential production areas that are agro-industrial farms dominated by human activities in the area. Thus these key pollutants can come in general from phytosanitary products especially the $\mathrm{NO}_{3}^{-}$. This important role of fertilizer production $\mathrm{NO}_{3}^{-}$indicated in the work of [4] showed that the use of these fertilizers leads to increased environmental problems marked by an increase in the content of $\mathrm{NO}_{3}^{-}$.

\section{Conclusion}

The results of this study highlight the impact of agro-industrials exploitations on groundwater resources. These results show that the concentrations of pollutants that are $\mathrm{Cl}^{-}, \mathrm{SO}_{4}^{2-}$ and $\mathrm{NO}_{3}^{-}$are still very high, but lower than the WHO standards with the exception of $\mathrm{NO}_{3}^{-}$with more than $50 \%$ of the parameters with a content greater 
than or equal to the standard and an average concentration of more than $53 \mathrm{~m} / \mathrm{L}$. The land use map highlights potential sources of pollution that are large banana plantations and oil palm observed respectively in the northern and southern parts of the study area

Statistical analysis using the SOM method revealed four classes that can be grouped into two main classes. A superficial origin class contains the pollutants from anthropogenic activities $\left(\mathrm{Cl}^{-}, \mathrm{SO}_{4}^{2-}\right.$ and $\left.\mathrm{NO}_{3}^{-}\right)$and those whose origin is related to the dissolution of rocks $\left(\mathrm{Fe}^{2+}\right.$, $\mathrm{Na}^{+}, \mathrm{K}^{+}, \mathrm{Mg}^{2+}, \mathrm{Ca}^{2+}, \mathrm{Mn}^{2+}$ ). The low concentrations of these parameters show that the mineralization of groundwater in the area is dominated by transfer of these settings since the surface to the depth. The superposition of these different sampling sites on the land use map confirms the importance of superficial origin of pollutants that are especially $\mathrm{Cl}^{-}, \mathrm{SO}_{4}^{2-}$ and $\mathrm{NO}_{3}^{-}$.

\section{Acknowledgements}

We thank the International Foundation for Science (IFS) for funding this research. We also thank villager's community for its availability and understanding.

\section{REFERENCES}

[1] H. Zhang and K. M. Hiscock, "Modeling the Effect of Forest Cover in Mitigating Nitrate Contamination of Groundwater: A Case Study of the Sherwood Sandstone Aquifer in the East Midlands, UK," Journal of Hydrology, Vol. 399, 2011, pp. 212-225. http://dx.doi.org/10.1016/j.jhydrol.2010.12.042

[2] N. P. Rajankar, D. H. Tambekar and S. R. Wate, "Groundwater Quality and Water Quality Index at Bhandara District," Environmental Monitoring and Assessment, Vol. 179, No. 4, 2011, pp. 619-625. http://dx.doi.org/10.1007/s10661-010-1767-y

[3] P. M. Vitousek, H. A. Mooney, J. Lubchenco and J. M. Melillo, "Human Domination of Earth's Ecosystems," Science Magazine, Vol. 277, No. 5325, 1997, pp. 494-499. http://dx.doi.org/10.1126/science.277.5325.494

[4] P. G. Taylor and A. R. Townsend, "Stoichiometric Control of Organic Carbon-Nitrate Relationships from Soils to the Sea," Nature, Vol. 464, 2010, pp. 1178-1181.

[5] J. P. R. Jourda, M. B. Saley, E. M. Djagoua, K. J. Kouamé, J. Biémi and M Razack, "Utilisation des Données ETM+ de Landsat et d'un SIG pour L'évaluation du Potentiel en eau Souterraine dans le Milieu Fissuré Précambrien de la Région de Korhogo (Nord de la Côte d'Ivoire): Approche par Analyse Multicritère et test de Validation," Télédétection, Vol. 5, No. 4, 2006, pp. 339-357.

[6] B. Dibi, K. I. Kouamé, A. B. Konan-Waidhet, I. Savane, J. Biemi, V. Nedeff and G. Lazar, "Impact of Agriculture on the Quality of Groundwater Resources in Peri-Urban Zone of Songon (Côte d'Ivoire)," Environmental Engineering and Management Journal, Vol. 12, 2012, pp. 2173-2182.

[7] B. Dibi, K. L. Kouassi, K. I. Kouamé, K. S. Konan, M.
Soumahoro, A. B. Konan-waidhet and D. Gnakri, "Evaluation de la Vulnérabilité à la Pollution des Aquifères des Formations Altérites à Partir des Méthodes DRASTIC et SYNTACS: Cas de la ville de M'bahiakro, Centre de la Côte d'Ivoire," International Journal of Innovation and Applied Studies, Vol. 2, No. 4, 2013, pp. 464-476.

[8] K. I. Kouamé, K. S. Konan, K. L. Kouassi, B. Dibi, M. Soumahoro, I. Savane and D. Gnakri, "Assessment of Wells Water Quality and Their Suitability for Drinking in M'bahiakro City (Côte d'Ivoire)," Internal Journal of Conservation Science, Vol. 3, No. 4, 2012, pp. 289-300.

[9] I. Doumouya, B. Dibi, K. I. Kouame, M. B. Saley, J. P. Jourda I. Savane and J. Biemi, "Modelling of Favourable Zones for the Establishment of Water Points by Geographical Information System (GIS) and Multicriteria Analysis (MCA) in the Aboisso Area (South-East of Côte d'Ivoire)," Environmental Earth Sciences, Vol. 67, 2012, pp. 1763-1780. http://dx.doi.org/10.1007/s12665-012-1622-2

[10] K. F. Konan, F. Leprieur, A. Ouattara, S. Brosse, G. Grenouillet, G. Gourène, P. Winterton and S. Lek, "SpatioTemporal Patterns of Fish Assemblages in Coastal West African Rivers: A Self-Organizing Map Approach," Aquatic Living Resources, Vol. 19, 2006, pp. 361-370. http://dx.doi.org/10.1051/alr:2007006

[11] S. Aw, E. B. Z. N'goran, S. Siaka and B. Parinet, "Intérêt de L'Analyse Multidimensionnelle Pour L'évaluation de la Qualité Physico-Chimique de l'eau d'un Système Lacustre Tropical: Cas des lacs de Yamoussoukro (Côte d'Ivoire)," Journal of Applied Biosciences, Vol. 38, 2011, pp. 2573-2585.

[12] APHA, "Standard Methods," American Public Health Association, Washington DC, 1995.

[13] T. Kohonen, "Self-Organized Formation of Topologically Correct Features Maps," Biological Cybernetics, Vol. 43, 1982, pp. 59-69. http://dx.doi.org/10.1007/BF00337288

[14] T. Kohonen, "Self-Organizing Maps," Springer-Verlag, Series in Informatique Sciences, 30, 1995, p. 362.

[15] D. E. Rumelhart, G. E. Hinton and R. J. Williams, "Learning Internal Representations by Error Propagation. In: Parallel Distributed Processing: Explorations in the Microstructure of Cognition, Foundations," MIT Press, Cambridge, 1986, pp. 318-362.

[16] S. Lek, J. L. Giraudel and J. F. Guégan, "Neuronal Networks: Algorithms and Architectures for Ecologists and Evolutionary Ecologists," In: S. Lek and J. F. Guégan, Eds., Artificial Neuronal Networks: Application to Ecology and Evolution, Springer-Verlag, Berlin, 2000, pp. 3-27. http://dx.doi.org/10.1007/978-3-642-57030-8 1

[17] S. Brosse, J. L. Giraudel and S. Lek, "Utilisation of NonSupervised Neural Networks and Principal Component Analysis to Study Fish Assemblages," Ecological Model, Vol. 146, 2001, pp. 159-166.

http://dx.doi.org/10.1016/S0304-3800(01)00303-9

[18] L. Cheng, S. Lek, S. Lek-Ang and Z. Li, "Predicting Fish Assemblages and Diversity in Shallow Lakes in the Yangtze River Basin," Limnologica, Vol. 42, 2012, pp. 127-136. http://dx.doi.org/10.1016/j.limno.2011.09.007

[19] G. W. Tyson, J. Chapman, P. Hugenholtz, E. E. Allen, R. J. Ram, P. M. Richardson, V. V. Solovyev, E. M. Rubin, 
D. S. Rokhsar and J. F. Banfield, "Community Structure and Metabolism through Reconstruction of Microbial Genomes from the Environment," Nature, Vol. 4, No. 428, 2004, pp. 37-43. http://dx.doi.org/10.1038/nature02340

[20] E. Alhoniemi, J. Himberg, J. Parhankangas and J. Vesanto, "SOM Toolbox, version 2.0 beta," 2005.

[21] L. F. Ibarra, R. A. Medina and H. Krawinkler, "Hysteretic Models that Incorporate Strength and Stiffness Deterioration," Earthquake Engineering and Structural Dynamics, Vol. 34, No. 12, 2005, pp. 1489-1511.

http://dx.doi.org/10.1002/eqe.495

[22] L. K. Medlin and M. Jungclaus, "Artificial Neural Networks Contribute to the Identification of Cryptomonad Taxa," Vie et Milieu, Vol. 62, No. 3, 2012, pp. 121-127.

[23] J. Vesanto and E. Alhoniemi, "Clustering of the Self-Organizing Map," IEEE Transactions on Neural Networks, Vol. 11, No. 3, 2000, pp. 586-600. http://dx.doi.org/10.1109/72.846731

[24] A. Marjoua and P. H. Olive et Jusserand, "Apports des Outils Chimiques et Isotopiques à L'Identification des Origines de la Salinisation des eaux: Cas de la Nappe de la Chaouia Cotière (Maroc)," Revue des sciences de l'eau, Vol. 4, 1997, pp. 489-505.

[25] ACF (Action Contre la Faim), "Eau-Assainissement-
Hygiène pour les Populations à Risques," Collection HERMANN, Editeur des Sciences des Arts, 2nd Edition augmentée, 2006, p. 744.

[26] J. E. Compton and R. D. Boone, "Long-Term Impacts of Agriculture on Soil Carbon and Nitrogen in New England Forests," Ecology, Vol. 81, 2000, pp. 2314-2330. http://dx.doi.org/10.1890/0012-9658(2000)081[2314:LTI OAO]2.0.CO;2

[27] F. T. Wakida and D. N. Lerner, "Potential Nitrate Leaching to Groundwater from House Building," Hydrological Processes, Vol. 20, No. 9, 2006, pp. 2077-2081. http://dx.doi.org/10.1002/hyp.6143

[28] D. Boust, B. Ouddane, J. C. Fischer, M. Wartel, D. Hebert and M. Roset, "Les Sédiments Anoxiques: Puits Temporaires et Sources Chroniques de Métaux-Traces dans L'Estuaire de la Seine," Colloque Seine Aval, 17-19 novembre 99, Mont-Saint-Aignan, 1999.

[29] A. Chambel and J. Duque, "Hard Rock Aquifers of Alentejo Region (South Portugal): Contribution to the Water and Land Use Managment. Proceedings of the XXIX IAH Congress, Hydrogeology and Land Use Management," In: M. Fendekova and M. Fendek, Eds., Bratislava, Slovakian Republic, 1999, pp. 171-176. 